\title{
Tablet Bilgisayarların Okul Öncesi Dönemde Resim Çiziminde Kullanılması
}

\author{
Funda Ergüleç ${ }^{1}$, Rahime Filiz Kiremit ${ }^{2}$
}

${ }^{1}$ Bilgisayar ve Öğretim Teknolojileri Bölümü, Eğitim Fakültesi, Eskişehir Osmangazi Üniversitesi, Eskişehir, Türkiye

${ }^{2}$ Temel Eğitim Bölümü, Ereğli Eğitim Fakültesi, Necmettin Erbakan Üniversitesi, Konya, Türkiye

Sorumlu Yazar: Funda Ergüleç, fergulec@ogu.edu.tr

Makale Türü: Araştırma Makalesi

Kaynak Gösterimi: Ergüleç, F., \& Kiremit, R. F. (2019). Tablet bilgisayarların okul öncesi dönemde resim çiziminde kullanılması. Eğitimde Kuram ve Uygulama, 15(1), 17-36. doi: 10.17244/eku.447167

\section{Exploring the Use of Tablet Computers for Drawing Activities in Early-Childhood Education}

Funda Ergüleç $^{1}$, Rahime Filiz Kiremit ${ }^{2}$

${ }^{1}$ Department of Instructional Technology, Faculty of Education, Eskişehir Osmangazi University, Eskişehir, Turkey

${ }^{2}$ Department of Elelmantary Education, Ereğli Faculty of Education, Necmettin Erbakan University, Konya, Turkey

Corresponding Author: Funda Ergüleç, fergulec@ ogu.edu.tr

Article Type: Research Article

To Cite This Article: Ergüleç, F., \& Kiremit, R. F. (2019). Tablet bilgisayarların okul öncesi dönemde resim çiziminde kullanılması. Eğitimde Kuram ve Uygulama, 15(1), 17-36. doi: 10.17244/eku.447167 


\title{
Tablet Bilgisayarların Okul Öncesi Dönemde Resim Çiziminde Kullanılması
}

\author{
Funda Ergüleç ${ }^{1}$, Rahime Filiz Kiremit ${ }^{2}$ \\ ${ }^{1}$ Bilgisayar ve Öğretim Teknolojileri Bölümü, Eğitim Fakültesi, Eskişehir Osmangazi Üniversitesi, Eskişehir, Türkiye \\ ORCID: https://orcid.org/0000-0002-7236-7894 \\ ${ }^{2}$ Temel Eğitim Bölümü, Ereğli Eğitim Fakültesi, Necmettin Erbakan Üniversitesi, Konya, Türkiye \\ ORCID: https://orcid.org/0000-0003-2418-1515
}

\begin{tabular}{|c|c|}
\hline$\ddot{\mathbf{O ̈ z}}$ & Makale Bilgisi \\
\hline $\begin{array}{l}\text { Bu çalışmanın amacı tablet bilgisayarların okul öncesi dönemde resim çizmek gibi } \\
\text { çocukların gelişimlerini destekleyen etkinliklerde kullanılabilirliğini belirlemektir. } \\
\text { Araştırmaya Konya ilinde yer alan özel bir okulun anasınıfına giden 3-6 yaş arası } 44 \text { (25 } \\
\text { kız, } 19 \text { erkek) çocuk, aileleri ve öğretmenleri dahil edilmiştir. Ailelere veli bilgi formları } \\
\text { dağıtılarak, evde bulunan teknolojik aletler, çocukların bu teknolojileri ne kadar ve ne } \\
\text { şekilde kullandıkları gibi sorular sorulmuştur. Çalışmanın ilk aşamasında, çocuklardan } \\
\text { kendi portrelerini bir kağıda çizmeleri istenmiştir. İkinci aşamasında çocuklara gerekli } \\
\text { eğitimler verilerek ve uygun ortam sağlanarak çocuklardan yine kendi portrelerini tablet } \\
\text { kalemi yardımı ile çizmeleri istenmiştir. Çizimler sonunda çocuklarla birebir görüşmeler } \\
\text { yapılmış ve tablet bilgisayarlarla çizdikleri resimler hakkında görüşleri alınmıştır. Daha } \\
\text { sonra çocukların resimleri öğretmenlere gösterilmiş ve çocukların çizdikleri her iki resmi } \\
\text { karşılaştırmaları istenmiştir. Bu görüşmeler sırasında öğretmenlere teknoloji ve tablet } \\
\text { bilgisayarlar hakkında görüşleri alınmak üzere sorular sorulmuştur. Araştırmada nitel } \\
\text { araştırma yöntem ve teknikleri kullanılmıştır. Araştırma verileri veli bilgi formları, } \\
\text { uygulama esnasındaki gözlemler ve video kayıtları, öğrenci görüşmeleri, öğretmen } \\
\text { görüşleri şeklinde toplanmış ve içerik analizi yöntemi ile analiz edilmiştir. Araştırmanın } \\
\text { bulgularına göre, tablet bilgisayarların eğitimde kullanılabilir olduğu, çocukların tablet } \\
\text { bilgisayarların kullanımı konusunda ilgili ve meraklı oldukları, çocukların tablet } \\
\text { bilgisayarlar ile yaptıkları resimlerin geleneksel yöntemle yaptıkları resimlerden daha } \\
\text { yaratıcı, detaylı ve renkli olduğu ve tabletteki çizim alanını daha verimli kullandıkları } \\
\text { tespit edilmiştir. Araştırmanın bulgularına dayalı olarak, velilere ve öğretmenlere yönelik } \\
\text { etkili ve verimli teknoloji kullanımı konusunda eğitimler verilmesi ve çocukların gelişen } \\
\text { teknolojiye uyum sağlamaları için sınıflarda teknolojinin doğru ve verimli bir şekilde } \\
\text { kullanımının arttırılması önerilmektedir. }\end{array}$ & $\begin{array}{l}\text { Makale Geçmişi: } \\
\text { Geliş: } 24 \text { Temmuz } 2018 \\
\text { Düzeltme: } 24 \text { Ekim } 2018 \\
\text { Kabul: } 27 \text { Kasım } 2018 \\
\text { Makale Türü: Araştırma } \\
\text { Makalesi }\end{array}$ \\
\hline
\end{tabular}




\section{Exploring the Use of Tablet Computers for Drawing Activities in Early-Childhood Education}

\begin{tabular}{|c|c|}
\hline Abstract & Article Info \\
\hline $\begin{array}{l}\text { The purpose of this study was to explore the viability of tablet computers in early } \\
\text { childhood education for activities that support children's developmental process. A total } \\
\text { of } 44 \text { three to six-year-old children, their parents, and teachers participated in the study. A } \\
\text { parent background survey was distributed and data was collected about the patterns of } \\
\text { children's technology use at home. In the first phase of the study, the children were asked } \\
\text { to draw their self-portraits in a traditional way with paper-and-pencil. In the second phase, } \\
\text { the children were asked to draw their self-portraits on tablet computer with a stylus. At the } \\
\text { end of the drawing sessions, the children were interviewed and questions were asked } \\
\text { about their drawings. Then, children's classroom teachers were asked to compare the } \\
\text { quality of drawings produced on the tablet with those produced in traditional way. The } \\
\text { study was designed and analyzed using qualitative methods and techniques, specifically } \\
\text { content analysis. The data included a parent background survey, observations and video } \\
\text { recordings during the drawing sessions, student interviews, and teacher focus group. The } \\
\text { study found the drawings on tablet computers to be more creative, detailed, and colorful } \\
\text { and drawing spaces on tablet computers were used more efficiently than a paper space. } \\
\text { The children were interested and persisted in learning with this new technology. The } \\
\text { stylus-interfaced technology appears to be a viable tool in early childhood education for } \\
\text { activities that support children's developmental process. It is suggested that trainings on } \\
\text { effective and efficient use of technology can be provided for parents and teachers and the } \\
\text { use of technology in a careful and efficient manner should be increased in the classroom } \\
\text { in order for the children to adapt to the developing technology. }\end{array}$ & $\begin{array}{l}\text { Keywords: Drawing in } \\
\text { preschool, Early-childhood } \\
\text { education, Educational } \\
\text { technology, Use of tablet } \\
\text { computers in early-childhood } \\
\text { education } \\
\text { Article History: } \\
\text { Received: } 24 \text { July } 2018 \\
\text { Revised: } 24 \text { October } 2018 \\
\text { Accepted: } 27 \text { November } 2018\end{array}$ \\
\hline
\end{tabular}




\section{Giriş}

Son yirmi yılda hayatımıza giren teknoloji kültürümüzü ve günlük yaşantımızı yakından etkilemektedir. Dijital kültür denildiğinde sadece bilgisayar ve internet kavramını anlamak yanlış olacaktır. Çünkü dijital kültür, mobil teknolojiyi, mobil telefonları, kablosuz bilgi iletişim teknolojilerini, e-kitapları ve oyunları da kapsamaktadır (Miller, 2011). İnternet, cep telefonları, bilgisayar oyunları, etkileşimli televizyonları içine alan dijital medya artık çocukların ve gençlerin boş zaman etkinliklerinin ayrılmaz bir parçası haline gelmiştir (Buckingham, 2007). Konu, boş zaman etkinliklerinden eğitimde teknoloji kullanımına geldiği zaman ise, günümüzde eğitimciler teknolojinin sınıflarda kullanılıp kullanılmayacağına, kullanılacaksa ne kadar kullanılacağına ilişkin sorulardan ziyade teknolojinin sınıflarda nasıl kullanılacağına ve eğitime nasıl dahil edileceğine yönelik sorulara yanıt aramaya başlamışlardır (Clements \& Sarama, 2014). Paralel şekilde, birçok ülkede, gelişen teknolojinin çocukların hayatındaki yeri ve etkisi tanınmıştır. $\mathrm{Bu}$ ülkeler artık teknolojinin çocukların gelişimsel süreçlerine uygun şekilde kullanılabileceği ders programları geliştirmeye başlamışlardır (McKenney \& Voogt, 2009; Plowman, Stevenson, McPake, Stephen, \& Adey, 2012).

Teknolojinin yaygınlaşması, eğitim-öğretim sürecinde de teknolojinin kullanılmasını sağlamıştır. Eğitim politikaları da bu süreçten etkilenmiş ve yeni eğitim projeleri geliştirilmeye başlanmıştır. Ülkemizde eğitimde teknoloji konusunda ise, FATİH Projesi (Fırsatları Artırma Teknolojiyi İyileştirme Hareketi) ilk olarak akla gelmektedir. FATİH Projesi teknolojinin derslerde etkin olarak kullanılması, öğrencilerin dersteki başarıları dışında ilgi alanları ve yaptıkları aktiviteler ile değerlendirilmesini sağlamak amacı ile dünya çapında en kapsamlı eğitim hareketi olarak başlatılmıştır (FATİH, y.y.). Türkiye'de 2013 yılında uygulamaya konulan FATİH Projesi ülkemizde okullarda teknolojiyi kullanımı konusunda bugüne kadar yapılmış en kapsamlı projelerden bir tanesidir. Aynı şekilde, diğer ülkelerde de, örneğin Brezilya'da "Um Computador por Alumno (UCA)” (her çocuğa bir dizüstü bilgisayar) projesi, Avustralya'da Dijital Eğitim Devrimi Projesi, Portekiz'de Macellan Projesi, Finlandiya'da Mobiluck Projesi dünyada teknolojinin eğitimde yeni yönelimlere gidildiğinin bir göstergesidir (Doğan, Çınar \& Seferoğlu, 2014; Tekin \& Polat, 2014). Farklı ülkelerdeki bu yenilikçi yaklaşımlara paralel olarak, okul öncesi alanında çalışan dünyanın önde gelen organizasyonları, araştırmacıları ve eğitimcileri, teknoloji kullanımının çocukların karar verme yeteneklerini geliştirdiğini, teknolojik aletlerin kullanımının yazma ve çizme gibi becerilerini geliştirdiğini, mantıksal ve analitik düşünme programlarının ise problem çözme ve fikir üretme yeteneklerini geliştirdiğini savunmaktadir (ISTE, 2017).

Çeşitli çalışmalar sonucunda, tablet bilgisayarların çocukların bilişsel, dil ve sosyal gelişimlerine katkısı olduğu kanıtlanmıştır (Neumann, 2014; Vernadakis, Avgerinos, Tsitskari \& Zachopoulou, 2005; Wong, 2015). Son zamanlarda yapılan bir çalışmada da tablette matematik ile ilgili bir uygulama kullanan çocukların matematik konusunda büyük bir öğrenme gelişimi gösterdikleri bulunmuştur (Outhwaite, Gulliford, \& Pitchford, 2017). Teknolojinin erken çocukluk döneminde kullanılmamasına yönelik yazılan bazı çalışmalar bulunmasına rağmen; birçok çalışmada erken çocukluk döneminde teknolojinin eğitimde kullanılmasının olumlu etkilerinden bahsedilmektedir. Bunlara örnek olarak şu çalışmalar verilebilir: erken çocukluk döneminde bilgisayar kullanımının çocuklarda kendine güven duygusu geliştirdiği ve problem çözme becerisi kazandırdığı bulunmuştur (McCarick \& Xiaoming, 2007); altı yaşındaki çocuklarda zaman ve mekân kavramları öğretilirken bilgisayar destekli öğretimin kullanılması, daha etkili ve nitelikli öğrenme gerçekleşmesine sebep olmuştur (Çeliköz \& Kol, 2013); erken çocukluk döneminde tablet kullanımın ise çocukların yaratıcılıklarını desteklediği ve kendilerini daha rahat ifade ettikleri görülmüştür (Özdemir \& Çetin, 2015).

Çocuklar 3-4 yaşlarından itibaren bilgisayarları keşfetmeye hazır hale gelirler ve bilgisayarların çocukların gelişimleri açısından önemli olduğu düşünülmektedir (Kesicioğlu, 2016). Akkoyunlu ve Tuğrul 
(2002)'e göre, bilgisayarların çocuklar tarafından küçük yaşlardan itibaren etkili bir şekilde kullanılması desteklenmelidir. Benzer şekilde, kitap, tebeşir, kara tahta gibi geleneksel materyallerin kullanıldığ okullarda eğitimin daha çok eğitimci merkezli olduğu, fakat teknolojik materyallerin dahil edildiği sınıflarda eğitimin daha çok çocuk merkezli olduğu düşünülmektedir (Bencik Kangal \& Özkızıkl1, 2015).

Okul öncesi sınıflarında, çocuklar kağıt, kalem, keçeli kalem, pastel boya, sulu boya, firça gibi birçok geleneksel araç ve gereçle çizim ve boyama yapmaktadır. Çizim ve boyama işlemlerinden, portre çizimi erken çocukluk eğitiminde çoğunlukla kullanılır ve çocuğun gelişimsel ilerlemesini anlamak için iyi bir ölçme aracıdır. "Bir insan çiz" testi de çocukların gelişimini anlamada kullanılan bir örnektir (Ter Laack, de Goede, \& Aleva, 2005; Özer, 2009). Bilgisayarların okul öncesi eğitimde kullanılmasının, çocukların renklere karşı olan ilgilerini arttırdığ 1 görülmüştür (Demir, 2007). Yapılan bir çalışmada, Trepanier-Street, Hong, ve Bauer (2001), çocukların bilgisayarda çizdiği resimlerin bazen daha detaylı olduğu ortaya çıkmıştır. Daha sonra yapılan bir çalışmada ise, Couse ve Chen (2010), bilgisayarda yapılan çizimlerin fare ile yapıldığını göz önünde bulundurarak, geleneksel yönteme daha yakın olan tablet ve kalemi kullanmıştır. Couse ve Chen (2010) tablette kalem ile yapılan çizimde çocukların daha ilgili ve çizimlerinin beklenenin üstünde olduğu bulunmuştur.

Ülkemizde tablet bilgisayar ve tablet kaleminin okul öncesi eğitiminde kullanılabilme potansiyeli hakkında yapılan herhangi bir çalışma bulunmamakla birlikte yurtdışında yapılan bazı çalışmalar teknolojinin erken çocukluk eğitiminde nasıl kullanılabileceği ile ilgili bilgi sağlamaktadır. Bu çalışma, tablet bilgisayarların çocuklar için benzersiz bir öğrenme deneyimi sunacağı göz önünde bulundurularak tablet bilgisayar ve kaleminin geleneksel kağıt kalem modeli ile kıyaslanması açısından önem taşımaktadır. $\mathrm{Bu}$ anlamda da tablet bilgisayar ve kaleminin erken çocukluk eğitiminde kullanılabilir teknolojik bir araç olup olmadığg incelenecektir.

\section{Araştırmanın Amacı}

Okul öncesi dönemde çocukların gelişimleri yaptıkları çalışmalar ile değerlendirilmektedir. Bu değerlendirmeler genelde çocukların serbest çizim ve yazım çalışmaları olarak düşünülebilir. Bu çalışma, tablet bilgisayarın bu anlamda eğitimde ne şekilde kullanılabileceğini anlamak için yapılmıştır. Bu amaç doğrultusunda okul öncesi dönem çocuklarından geleneksel bir yöntem olan kağıt kalem ile resim çizmeleri ve tablet bilgisayarlar ile resim çizmeleri istenmiştir.

\section{Araş̧ırmanın Problemi}

$\mathrm{Bu}$ amaç doğrultusunda araştırmanın problemleri şunlardır;

1. Okul öncesi dönem çocuklarının teknoloji ile ilişkilerinde veli görüşleri nelerdir?

2. Okul öncesi dönem çocuklarının tablet bilgisayarlarla resim çizmek hakkında düşünceleri nelerdir?

3. Okul öncesi dönem öğretmenlerinin ve araştırmacıların çocukların tablet bilgisayarlar ile çizdikleri resimler hakkında görüşleri nelerdir?

4. Okul öncesi dönem öğretmenlerinin çocukların teknoloji kullanımları konusunda görüşleri nelerdir?

\section{Yöntem}

\section{Araştırmanın Modeli}

Yapılan bu keşifsel araştırma (exploratory research) (Creswell \& Creswell, 2017), okul öncesi dönem çocuklarının tablet bilgisayar kullanımı konusundaki deneyimlerini incelemek ve bu teknolojik araçların öğrenme aracı olarak kullanılabilmesi konusunda daha detaylı bilgi edinmek için yapılmıştır. Çalışmada çeşitli veri toplama araçları kullanılarak, konu daha detaylı bir şekilde incelenmiş ve araştırmacıların yorumlarının geçerliliğini artırmak amaçlanmıştır (Yin, 2009). Çalışmadaki analiz ünitesi okul öncesi dönem çocukları olarak belirlenmiş ve bu çocukların hem geleneksel (kalem kâğıt, keçeli boya, pastel boya) yöntemlerle hem de tablet bilgisayar ve kalemi ile olan etkileşimi araştırılmıştır. 


\section{Çalışma Grubu}

$\mathrm{Bu}$ araştırma 2017-2018 bahar döneminde özel bir okula bağlı anaokuluna giden çocuklar ile yapılmıştır. Araştırmada Konya ilinde yer alan bir okul belirlenmiş ve anaokuluna giden bütün çocuklar araştırmaya dahil edilmiştir. Çalışmaya başlamadan önce Milli Eğitim Bakanlığından seçilen okulda çalışma yapılmasına yönelik olarak gerekli izinler alınmıştır. Alınan bu izin doğrultusunda önce okul müdürü ile görüşülmüş ve çalışmanın o okula bağlı anaokuluna giden bütün çocuklar ile yapılmasına karar verilmiştir. Okul müdürü ve çalışmaya katılacak diğer öğretmenlere çalışma hakkında genel bilgiler verildikten sonra velilere de bilgilendirme mektubu yazılmış, çocuklarının çalışmaya katılmalarına yönelik olarak gerekli izinler alınmıştır. Araştırmanın çalışma grubunu 3-6 yaş arası 44 (25 kız, 19 erkek) çocuk oluşturmaktadır. 3 yaş grubundan 7, 4 yaş grubundan 5, 5 yaş grubundan 14, 6 yaş grubundan 18 çocuk katılmıştır. Ayrıca bu çocukların gittikleri sınıflardaki 3 öğretmen de çalışmaya katılmıştır.

Araştırmaya katılan çocukların velilerine Teknoloji Çocuk Bilgi Formu verilmiş ve 44 aileden 37 tanesi formları doldurarak geri dönüş yapmışlardır. Ailelerden alınan bilgilere göre araştırmaya katılan çocukların kardeş sayıları 0 ila 3 kardeş arasında değişmektedir ve evde bilgisayar, tablet ve akıllı telefon kullanım oranları tablo 1'de gösterilmiştir. Çalışmaya katılan öğretmenlere mesleki kıdemleri hakkında soru sorularak not alınmıştır. Öğretmenlerin cinsiyet, görev yeri ve mesleki kıdem bilgileri de tablo 2'de belirtilmiştir.

Tablo 1. Yaş grubu dağılımı

\begin{tabular}{|c|c|c|c|c|c|c|c|}
\hline $\begin{array}{c}\text { Yaş } \\
\text { Grubu }\end{array}$ & $\mathbf{n}$ & Cinsiyet & $\mathbf{n}$ & $\begin{array}{c}\text { Evde } \\
\text { televizyon } \\
\text { izleme } \\
\text { (ortalama) }\end{array}$ & $\begin{array}{c}\text { Evde bilgisayar } \\
\text { kullanımı } \\
\text { (ortalama) }\end{array}$ & $\begin{array}{c}\text { Evde tablet } \\
\text { kullanımı } \\
\text { (ortalama) }\end{array}$ & $\begin{array}{c}\text { Evde akıllı } \\
\text { telefon } \\
\text { kullanımı } \\
\text { (ortalama) }\end{array}$ \\
\hline \multirow{2}{*}{3 yaş } & \multirow[b]{2}{*}{7} & $\mathrm{~K}_{1 \mathrm{Z}}$ & 3 & \multirow[b]{2}{*}{90 dakika } & \multirow{2}{*}{ - } & \multirow[b]{2}{*}{90 dakika } & \multirow{2}{*}{30 dakika } \\
\hline & & Erkek & 4 & & & & \\
\hline \multirow{2}{*}{4 yaş } & \multirow{2}{*}{5} & $\mathrm{~K}_{1 \mathrm{Z}}$ & 3 & \multirow{2}{*}{55 dakika } & \multirow{2}{*}{30 dakika } & \multirow{2}{*}{80 dakika } & \multirow{2}{*}{65 dakika } \\
\hline & & Erkek & 2 & & & & \\
\hline \multirow{2}{*}{5 yaş } & \multirow{2}{*}{14} & $\mathrm{~K}_{1 \mathrm{Z}}$ & 6 & \multirow{2}{*}{95 dakika } & \multirow{2}{*}{60 dakika } & \multirow{2}{*}{120 dakika } & \multirow{2}{*}{50 dakika } \\
\hline & & Erkek & 8 & & & & \\
\hline \multirow{2}{*}{6 yaş } & \multirow{2}{*}{18} & $\mathrm{~K}_{1 \mathrm{Z}}$ & 10 & \multirow{2}{*}{60 dakika } & \multirow{2}{*}{ - } & \multirow{2}{*}{60 dakika } & \multirow{2}{*}{30 dakika } \\
\hline & & Erkek & 8 & & & & \\
\hline Toplam & 44 & & & & & & \\
\hline
\end{tabular}

Tablo 2. Öğretmen bilgisi

\begin{tabular}{cccc}
\hline Kod adı & Cinsiyet & Görev Yeri & Mesleki Kıdem \\
\hline Ö1 & Kadın & Konya-Anasınıfı & 7 yıl \\
\hline Ö2 & Kadın & Konya-Anasınıfı & 5 yıl \\
\hline Ö3 & Kadın & Konya-Anasınıfı & 2 yıl \\
\hline
\end{tabular}

\section{Veri Toplama Araçları}

Araştırmada çocukların ev ortamında kullandıkları teknolojik aletler ve teknolojiyle ne kadar ilişkili olduklarını belirlemek amacı ile velilere verilmek üzere Teknoloji Çocuk Bilgi Formu hazırlanmıştır. Bu form aile ortamında teknoloji kullanımı ve velilerin teknolojiye bakış açısını görmek için tanımlayıcı (descriptive) bir veri toplama aracı olarak uygulanmıştır. Çalışmanın inanılırlığını (credibility) artırmak için, Teknoloji Çocuk Bilgi Formundaki sorular, uzman incelemesi (peer debriefing) (Creswell \& Creswell, 2017) kapsamında teknoloji konusunda genel bilgiye sahip 3 uzman tarafından incelenmiş ve katılımc1 
teyidi (member checking) (Yıldırım \& Şimşek, 2013) kapsamında da 3 veli ile soruların anlaşılabilirliğinin ve amaca uygunluğunun test edilmesi için ön uygulaması yapılmıştır. Uzmanlardan ve velilerden gelen dönütler doğrultusunda form sorularına son hali verilmiştir. Teknoloji Çocuk Bilgi Formunda çocukların doğum tarihleri, kardeş sayıları, cinsiyetleri, evde bulunan teknolojik aletler, çocukların evde bulunan teknolojik aletler ile geçirdikleri süre, ailelerin teknolojik aletlerde yer alan eğitici ve öğretici uygulamalar hakkındaki görüşleri, ücretli olarak satın aldıkları uygulamalar olup olmadığı ve bu uygulamaların neler olduğu hakkında sorular yer almaktadır.

Uygulama esnasında, çocukların söyledikleri ve yaptıklarının (ör. hangi tuşa basıldığı, yanlış yapılan bir işlemin geri alınması, silinmesi, renk seçimi) kayıt edilmesi amacı ile video kayıt cihazı ile görüşmeler kayıt altına alınmıştır. Video kayıtlarına ek olarak, her bir çocuğun kağıt ve tablet çizimleri veri olarak toplanmış ve analiz edilmiştir. Çocuklara uygulama esnasında sorulacak maddelerden oluşan görüşme formu okul öncesi ve teknoloji alanında 2 uzman tarafından incelenmiştir. Ardından maddelerin anlaş1lırlığı ve amaca uygunluğunun belirlenmesi için 3 yaşından 1 çocuk, 4 yaşından 1 çocuk ve 6 yaşından 1 çocuk ile ön görüşmeler yapılmıştır ve çocukların anlamadıkları veya araştırmanın amacı dışında görülen maddeler çıkarılmış ve görüşme formuna son hali verilmiştir. Görüşme formunda, çocuklara tablette resim çizmek hakkında neler düşündükleri, tablette resim çizerken en çok neyi sevdikleri ya da neyi sevmedikleri, tablette başka neler çizmek istedikleri, tablette resim çizmeyi mi yoksa kağıt kalem ile resim çizmeyi mi tercih ettikleri, tablette yapıp kağıt kalem ile yapamadıkları, kağıt kalem ile yapıp tablette yapamadıkları etkinlikler hakkında sorular sorulmuştur. Her bir çocuğun kağıt ve tablet çizimleri hakkındaki öğretmen görüşlerini toplamak için yarı yapılandırılmış bir odak grup görüşme formu oluşturulmuştur. Odak grup görüşmesinde öğretmenlere çizimler hakkında görüşleri sorulmuştur.

\section{Verilerin Toplanması}

Çalışmada verilerin toplanması 6 ana aşamadan oluşmaktadır (Figür 1). İlk aşamada velilere çalışma bilgilendirme mektubu yazılmış ve çocuklarının çalışmaya katılmalarına yönelik gerekli izinler alınmıştır. Aynı aşamada, çalışmaya katılan velilerden Teknoloji Bilgi Formunu doldurmaları istenmiştir. 2. aşamada, her bir sınıf öğretmeni çocuklardan kendi portrelerini bir kağıda çizmelerini istemiştir. 3. aşamada, her bir çocuğa tabletin ve çizim esnasında kullanılacak olan uygulamanın nasıl kullanılacağı hakkında bilgiler verilerek hem tanışma hem de araştırmacılara uyum sağlama için bir ortam yaratılmıştır. 4. aşamada, çocuklardan kendi portrelerini anlatılan uygulamada çizmesi istenmiştir. 5. aşamada, çocuklarla kullanılan uygulama ve genel olarak tablet hakkındaki görüşlerini öğrenmek için görüşmeler yapılmıştır. 6. aşamada, öğretmenler ile odak grup görüşmesi yapılarak öğretmenlerin her bir çocuğun kağıt ve tablet çizimlerini karş1laştırarak düşüncelerini belirtmeleri istenmiştir.

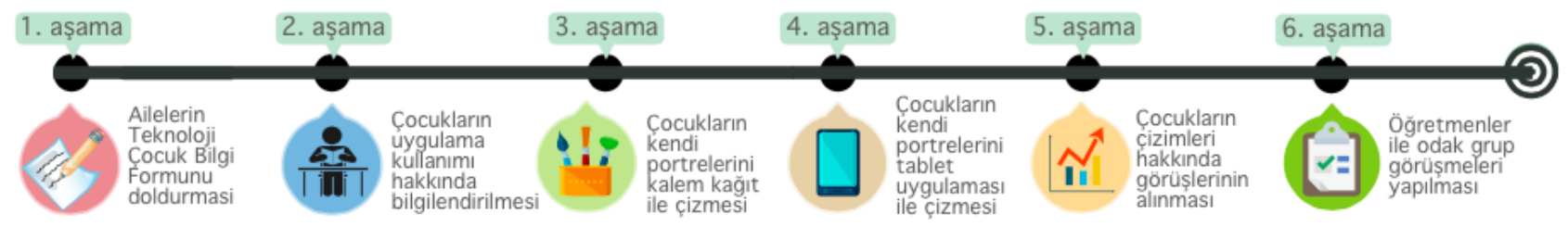

Figür 1. Çalışma aşamaları

Çalışmanın başladığı ilk hafta, her bir sınıf öğretmeni çocuklardan kendi portrelerini bir kağıda çizmelerini istemiş̧tir. Portrelerin kağıda çizilmesi esnasında kağıt, kalem, keçeli kalem, pastel boya, sulu boya, fırça gibi birçok geleneksel araç ve gereç çocukların kullanımına açılmıştır ve istediklerini seçebilecekleri bir ortam hazırlanmıştır. Daha sonraki hafta, araştırmacılar devreye girerek, iki araştırmacı okulda üç hafta boyunca verileri toplamıştır. Çocukların araştırmacı ile kendilerini rahat hissetmeleri için araştırmacılardan bir tanesi verileri toplamadan önce iki gün boyunca sınıflarda çocuklarla vakit geçirmiştir. Her seferinde sadece tek bir çocuk olacak şekilde çocukları sınıf ortamından ayrı bir odaya alarak görüşmeler yapılmıştır. Veri toplama sürecinde, araştırmacılardan bir tanesi kayıt cihazlarının kurulması ve 
kullanılmasından sorumlu olmuş, çocukları odaya davet ederek oturmaları için yer göstermiş̧tir. Diğer araştırmacı ise, çalışmayı yaş grubuna uygun bir dille anlatarak, tabletteki uygulamanın nasıl kullanıldığından bahsetmiştir. Yine aynı araştırmacı resim çizme etkinliği boyunca çocukların yanında yer alarak tableti ve uygulamayı rahat kullanabilecekleri bir ortam sağlamıştır. Çizimler esnasında, araştırmacılar ve öğretmenler çocukların çizimlerine hiçbir şekilde müdahale etmemiştir. Son olarak, etkinlik sonrasında çocuklara görüşme sorularını sormuştur. Her iki çizim sırasında da çocuklara süre kısıtlaması yapılmamış ve çalışmalarını bitirme süresi çocukların tercihlerine bırakılmıştır.

Çocuklar ile yapılan her bir görüşme ortalama 15-20 dakika sürmüştür. Araştırmaya katılan çocukların ve öğretmenlerin gerçek isimleri kullanılmamış çocuklar Ç1, Ç2, Ç3...Ç44 şeklinde, öğretmenleri de Ö1, Ö2, Ö3 şeklinde kodlanmıştır. Çocukların kodlamalarına göre cinsiyetleri ve yaşları Ek-1'de gösterilmiştir. Çalışmanın en son aşamasında, öğretmenler ile 55 dakikalık bir odak grup görüşmesi yapılarak öğretmenlerin her bir çocuğun kağıt ve tablet çizimlerini karşılaştırarak düşüncelerini belirtmeleri istenmiştir. Görüşmeler okuldaki bir toplantı salonunda yapılmış ve daha sonra yazıya aktarılmak üzere ses kayıt cihazı ile kayıt edilmiştir.

Çalışmada portre seçilmesinin sebebi, her çizimi belirli bir standarda sokarak, çocukların daha rahat ve ortak çizebilecekleri bir resim belirlemektir. Kağıt ve tablet çizimleri esnasında, çocukların kendilerini rahatlıkla görebileceği bir yere yüz aynası yerleştirilmiştir. Böylelikle, çocukların saç, göz, ağız ve burun gibi diğer yüz özelliklerinin farkına varması sağlanarak, çizerken kendilerine bakmalarına izin verilmiştir.

\section{Verilerin Analizi}

Araştırmadaki verilerin analizinde, nitel analiz yöntem ve tekniklerinden (Bogden \& Biklen, 2007), içerik analizi yöntemi kullanılmıştır. "İçerik analizi, hacimli olan nitel materyali alarak temel tutarlılıkları ve anlamları belirlemeye yönelik herhangi bir nitel veri indirgeme ve anlamlandırma çabasıdır" (Patton, 2014, s. 453). Öncelikle, tüm tablet ve kağıtta yapılan çizimler, çocuk görüşmelerinin transkriptleri ve çocukların resimleri için öğretmen odak grup görüşme verileri bir araya getirilmiştir. Kağıtta yapılan çizimler geleneksel formda, tablette yapılan çizimler ise elektronik formda toplanmıştır. İlk olarak, bütün görüşme verileri araştırmacılardan biri tarafından yazıya aktarılmıştır. Çocuk görüşmeleri 15-20 dakika arasında gerçekleşmiş ve her bir çocuk için ortalama 1 sayfalık döküman elde edilmiştir. Çalışmaya katılan 3 öğretmen ile tek bir odak grup görüşmesi yapılmış ve görüşme 55 dakika sürmüştür, bu görüşme verileri de yazıya aktarılarak 8 sayfalık bir döküman elde edilmiştir.

Daha sonra, iki araştırmacı aktarılan yazıları ayrı ayrı okuyarak, araştırmada içerik analizi yöntemi ile görüşmelerden elde edilen verilere dayalı olarak öncelikle kodları belirlemişlerdir. Bu kodlar; evde bulunan teknolojik aletler, velilerin çocuklarına teknolojik alet kullanımı konusunda izin vermeleri, tablette bulunan uygulamalar, velilerin teknolojiye yönelik düşünceleri; çocukların tablet kullanımına yönelik düşünceleri, çocukların tablette çizmek istedikleri resimler, çocukların çizdikleri resimler hakkındaki düşünceleri; öğretmenlerin çocukların resimlerine yorumları, öğretmenlerin çocukların tablet kullanımına ilişkin yorumları, araştırmacıların çocukların resimleri yorumları şeklindedir. Bu kodlar listesinde birbiri ile ilişkili olan durumlar belirlenmiş ve kategoriler altına alınmıştır. Bu kodlamalar çocuklar, veliler, öğretmenler ve akademisyenler olarak gruplara ayrılarak kategori başlıkları belirlenmiştir. Bu kategoriler; velilerin çocuklarının evde teknoloji kullanımına yönelik tutumları, velilerin çocuklarına tablette kullandırdıkları uygulamalar, velilerin teknolojiye yönelik kişisel duygu düşünceleri; çocukların tablet kullanımına ilişkin duyguları, çocukların tablet kullanımına yönelik olumlu düşünceleri, çocukların tablet kullanımına yönelik olumsuz düşünceleri, çocukların tablette resim çizmek dışındaki tercihleri, çocukların tablette resim çizmek hakkındaki görüşleri; öğretmenlerin çocukların resimlerine yorumları, öğretmenlerin çocukların tablet kullanımına yorumları, araştırmacıların çocukların resimlerine yorumları şeklindedir. 
Kategoriler de oluşturulduktan sonra temalar elde edilmiştir. Bu temalar; velilerin teknolojiye yaklaşımları, çocukların teknoloji/tablet kullanımına yaklaşımları, öğretmenlerin ve araştırmacıların çocukların çizdikleri resimlere ve çocukların tablet kullanımlarına yönelik yaklaşımları şeklindedir.

Çocukların görüşme sırasında söyledikleri ve uygulama sırasında yaptıklarının tutarlılığı için çekilen video kayıtları çocuk görüşme verilerine destek olarak kullanılmıştır. Video kayıtlarındaki çocukların davranışları (ör. hangi tuşa basıldığı, yanlış yapılan bir işlemin geri alınması, silinmesi, renk seçimi), ELAN (Wittenburg, Brugman, Russel, Klassmann, \& Sloetjes, 2006) adlı nitel araştırma yazılımı aracıyla kodlanmıştır. Son olarak, çocukların verileri öğretmen görüşleriyle de desteklenerek sonuçlar elde edilmiştir.

Ayrıca, geleneksel yöntem ve tablet ile çizilen resimler araştırmacılar tarafından da belirli kriterlere dayanarak değerlendirilmiştir. Kullanılan renk sayısı, çizilen nesne sayısı, nesne farklılığı, çizilen portrenin büyüklüğü ve resim alanının kullanım şekli gibi kriterlere bakılarak geleneksel ve tablet resimleri arasında seçim yapılmıştır. Seçim aşamasında objektifliğin sağlanması için, iki araştırmacı da resimleri ayrı ayrı değerlendirmiş ve değerlendirmelerini karşılaştırarak karara varmışlardır.

Araştırmacılar verilerin geçerlik ve güvenirliği için veri çeşitlemesi ve veri derinliğinden yararlanmıştır. Veri çeşitliliğini sağlamak için sadece çocuklarla değil aynı zamanda öğretmenler ile de görüşmeler yapılmış ve öğretmenlerin hem kağıt hem de tablet çizimleri değerlendirmesi sağlanmıştır. Ayrıca, çocuklar çizim yaparken video kaydı alınarak, söyledikleri ve yaptıklarının tutarlılığı incelenmiştir. Video kayıtları, çocuk görüşmeleri, öğretmen görüşmeleri, veli bilgi formu yoluyla derin ve detaylı veri toplanmıştır. Ayrıca, bu yaş grubu çocuklarda oluşabilecek gözlenmenin yarattığı fiziksel ve psikolojik etkiler göz önünde bulundurularak, ölçmenin çocuklara olan etkisini azaltmak için veri toplamadan önce araştırmacılardan bir tanesi çocuklarla vakit geçirmiş ve etkinlikler yapmıştır. Böylece araştırmanın geçerlik ve güvenirliği arttırılmıştır. Buna ek olarak, verilerin analiz güvenilirliği için iki araştırmacı bulgularını karşılaştırarak karara varmış ve bulguların bir özeti hazırlanarak katılımcı kontrolü yöntemi (member check) (Yıldırım \& Şimşek, 2013) ile araştırmacı yorumlarının doğruluğu öğretmenlerle teyit edilmiştir.

\section{Bulgular}

$\mathrm{Bu}$ bölümde velilerden, çocuklardan, öğretmenlerden ve araştırmacılardan alınan verilerden elde edilen bulgulara yer verilmiştir. Yapılan analizler sonucunda elde edilen veriler 3 temada sunulmuştur. Oluşturulan temalar Tablo 3'de gösterilmiştir.

Tablo 3. Temalar

\section{Tema Başlıkları}

Velilerin teknolojiye yaklaşımları

Çocukların teknoloji/tablet kullanımına yaklaşımları

Öğretmenlerin ve araştırmacıların çocukların çizdikleri resimlere ve çocukların tablet kullanımlarına yönelik yaklaşımları

\section{Velilerin Teknolojiye Yaklaşımları Teması}

Araştırmaya katılan velilerin teknolojiye yaklaşımları; velilerin çocuklarının evde teknoloji kullanımına yönelik tutumları, velilerin çocuklarına tablette kullandırdıkları uygulamalar, velilerin teknolojiye yönelik kişisel duygu düşünceleri kategorilerinde Tablo 4'de incelenmiş ve kodlamalara yer verilmiştir.

Tablo 4. Velilerin Teknolojiye Yaklaşımları Temasına İlişkin Kategori ve Kodlamalar

Kategori 1:

Velilerin çocuklarının evde teknoloji kullanımına yönelik tutumlarına ilişkin
Kategori 2:

Velilerin çocuklarına tablette kullandırdıkları uygulamalara ilişkin kodlamalar
Kategori 3: Velilerin teknolojiye yönelik kişisel duygu düşüncelerine ilişkin kodlamalar 


\section{kodlamalar}

\begin{tabular}{clll}
\hline $\begin{array}{c}\text { KKod } \\
\mathbf{1}\end{array}$ & Evde bulunan teknolojik aletler & $\begin{array}{l}\text { Eğitime yönelik filmler ve } \\
\text { oyunlar }\end{array}$ & Olumlu duygu düşünce \\
$\begin{array}{c}\text { KKod } \\
\mathbf{2}\end{array}$ & $\begin{array}{l}\text { Velilerin teknoloji kullanımı } \\
\text { konusunda çocuklarına izin } \\
\text { vermeleri }\end{array}$ & Derslere yönelik uygulamalar & Olumsuz duygu düşünce \\
\hline
\end{tabular}

Tablo 4 incelendiğinde Kategori 1 de velilerin çocuklarının evde teknoloji kullanımına yönelik tutumlarına ilişkin kodlamalar yer almaktadır. Bu kodlamalara göre;

Kod1. Evde bulunan teknolojik aletler: Araştırmaya katılan ailelerin evlerinde televizyon ( $\mathrm{f}=37$ ), masaüstü bilgisayar $(\mathrm{f}=6)$, dizüstü bilgisayar $(\mathrm{f}=23)$, tablet $(\mathrm{f}=22)$, ak1llı telefon $(\mathrm{f}=36)$ gibi teknolojik aletler bulunmaktadır. Kod2. Velilerin teknoloji kullanımı konusunda çocuklarına izin vermeleri: Araştırmanın bulgularına göre çocukların evde günlük 10 dakika ila 4 saat aralığında teknoloji kullandığı ortaya çıkmıştır. Evde teknoloji kullanmayan çocuk bulunmamaktadır. Çocukların teknoloji kullanımın aletlere göre dağılımı ise, televizyon (15 dakika ila 2 saat), dizüstü bilgisayar (30 dakika ila 1 saat), tablet (30 dakika ila 4 saat), akıllı telefon (10 dakika ila 2 saat) olarak belirlenmiştir.

Tablo 4 incelendiğinde Kategori 2 de velilerin çocuklarına tablette kullandırdıkları uygulamalara ilişkin kodlamalar yer almaktadır. Bu kodlamalara göre;

Araştırmaya katılan velilerden alınan verilere göre, çocukların tablette kullandıkları uygulamaların genellemesi şu şekildedir: Kod1. Eğitime yönelik filmler ve oyunlar: eğitici çizgi filmler ( $\mathrm{f}=7$; Ç6, Ç12, Ç26, Ç28, Ç34, Ç41, Ç42), eğitici oyunlar (f=7; Ç1, Ç7, Ç15, Ç26, Ç33, Ç35, Ç40, Ç48), Kod2. Derslere yönelik uygulamalar: İngilizce öğreten uygulamalar (f=8; Ç1, Ç9, Ç12, Ç29, Ç36, Ç37, Ç39, Ç41), matematik bilgisine yönelik uygulamalar ( $\mathrm{f}=5$; Ç12, Ç13, Ç15, Ç32, Ç33).

Tablo 4 incelendiğinde Kategori 3 de velilerin teknolojiye yönelik kişisel duygu düşüncelerine ilişkin kodlamalar yer almaktadır. Bu kodlamalara göre;

Kod1. Olumlu duygu düşünceler: Velilerden çoğunluğu eğitici çizgi filmler, eğitici oyunlar, öğretici uygulamalar gibi cevaplar vererek teknolojiye yönelik olumlu tutumlarını dile getirmiştir. Bu yorumlardan bazıları şu şekildedir: "İngilizce Oyunlu Kelime Aktiviteleri," "Eğitici ve zeka geliştirici oyunlar," "Zeka oyunları," "Rakam öğrenme ve yazma bilgileri," "Okul öncesi eğitici programlar," "Toplama ve çıkarma," "English for Kids," "İngilizce Boyama sayfası," "6-8 parçalı yapboz," "Eşleştirme," "Sudoku," "Öğretici bilgilendirici çizgifilm,” ve "Öğretici şarkılar.” Buna ek olarak, Ç32: "Bazen kendi video çekip Youtube'a yüklüyor. Kendine olan güveninin arttığını düşünüyorum” diyerek teknolojinin kendi çocuğu üzerindeki olumlu etkisinden bahsetmiştir. Araştırmaya katılan velilerin sadece bir tanesi (Ç18) çocuğunun tablette kullanması için ücretli olan bir "satranç" uygulamasını satın aldığını ifade etmiştir. Kod2. Olumsuz duygu düşünceler: Araştırmaya katılan 2 velinin (Ç23, Ç31) teknoloji ve tablet kullanımına olumsuz baktıkları görülmüştür. Örnek olarak, Ç31: "Bizde eğitici ve öğretici hiçbir uygulama yok. Teknolojiyle bu kadar erken karşılaşmaları uygun değil” diyerek olumsuz görüşünü belirtmiştir.

\section{Çocukların Teknoloji/Tablet Kullanımına Yaklaşımları Teması}

Araştırmaya katılan çocukların teknolojiye ve tablet kullanımına yaklaşımları; çocukların tablet kullanımına ilişkin duyguları, çocukların tablet kullanımına yönelik olumlu düşünceleri, çocukların tablet kullanımına yönelik olumsuz düşünceleri, çocukların tablette resim çizmek dışındaki tercihleri, çocukların tablette resim çizmek hakkındaki görüşleri kategorilerinde Tablo 5'de incelenmiş ve kodlamalara yer verilmiştir. 
Tablo 5. Çocukların Teknoloji/Tablet Kullanımına Yaklaşımları Temasına İlişkin Kategori ve Kodlamalar

\begin{tabular}{|c|c|c|c|c|c|}
\hline & $\begin{array}{l}\text { Kategori 1: } \\
\text { Çocukların tablet } \\
\text { kullanıma yönelik } \\
\text { duygularına ilişkin } \\
\text { kodlamalar }\end{array}$ & $\begin{array}{l}\text { Kategori 2: } \\
\text { Çocukların tablet } \\
\text { kullanıma yönelik } \\
\text { olumlu } \\
\text { düşüncelerine } \\
\text { ilişkin kodlamalar }\end{array}$ & $\begin{array}{l}\text { Kategori 3: Çocukların } \\
\text { tablet kullanıma } \\
\text { yönelik olumsuz } \\
\text { düşüncelerine ilişkin } \\
\text { kodlamalar }\end{array}$ & $\begin{array}{l}\text { Kategori } 4 . \\
\text { Çocukların tablette } \\
\text { resim çizmek } \\
\text { dışındaki } \\
\text { tercihlerine ilişkin } \\
\text { kodlamalar }\end{array}$ & $\begin{array}{l}\text { Kategori } 5 . \\
\text { Çocukların tablette } \\
\text { resim çizmek } \\
\text { hakkındaki } \\
\text { görüşlerine ilişkin } \\
\text { kodlamalar }\end{array}$ \\
\hline $\begin{array}{c}\text { KKod } \\
1\end{array}$ & Soyut Duygular & $\begin{array}{l}\text { Kendi resimlerine } \\
\text { yönelik düşünceler }\end{array}$ & $\begin{array}{l}\text { Kendi resimlerine } \\
\text { yönelik düşünceler }\end{array}$ & Farklı nesneler & Olumlu düşünceler \\
\hline $\operatorname{Kod} 2$ & Somut Duygular & $\begin{array}{c}\text { Tablete ve } \\
\text { Uygulamaya } \\
\text { yönelik düşünceler }\end{array}$ & $\begin{array}{l}\text { Tablete ve Uygulamaya } \\
\text { yönelik düşünceler }\end{array}$ & Aile bireyleri & Olumsuz düşünceler \\
\hline $\operatorname{Kod} 3$ & - & - & - & Hayvanlar & - \\
\hline
\end{tabular}

Tablo 5 incelendiğinde Kategori 1 de çocukların tablet kullanıma yönelik duygularına ilişkin kodlamalar yer almaktadır. Bu kodlamalara göre;

Kod1. Soyut duygular: Araştırmaya katılan çocuklara, tablette resim çizdikten sonra neler hissettikleri sorulmuş ve çocuklar hislerini anlatırken güzel ( $\mathrm{f}=22$; Ç3, Ç4, Ç5, Ç6, Ç7, Ç10, Ç11, Ç12, Ç15, Ç17, Ç18, Ç19, Ç22, Ç24, Ç25, Ç27, Ç28, Ç29, Ç30, Ç35, Ç38, Ç40), heyecanlı (f=4; Ç2, Ç18, Ç28, Ç37), eğlenceli ( $\mathrm{f}=3$; Ç20, Ç27, Ç44), rahat ( $\mathrm{f}=1$; Ç14), kolay ( $\mathrm{f}=1$; Ç26), keyifli ( $\mathrm{f}=1 ;$ Ç1), mutlu ( $\mathrm{f}=1$; Ç16) cevaplarını verirken, az sayıda ( $\mathrm{f}=3$; Ç13, Ç21, Ç23) çocuk neler hissettiğini belirtmemiştir. Ç1: "Normal resimden daha çok keyif aldım". Ç9: "Çok eğlendim ve çok da sevdim. Çünkü tabletlerle oynamayı seviyorum”. Kod2. Somut duygular: Özellikle, 36-48 yaş aralığında çocuklar neler hissettiklerini belirtirken anne ( $\mathrm{f}=1$; Ç44), baba ( $\mathrm{f}=1 ;$ Ç36), abla $(\mathrm{f}=1 ;$ Ç32), deniz $(\mathrm{f}=2$; Ç33, Ç34), araba $(\mathrm{f}=1 ;$ Ç43) gibi daha somut kavramları kullanarak duygularını ifade etmeye çalışmışlardır. Ç34: "Bir denizde bulmuştum kendimi" diyerek hissettiği duyguları somutlaştırmaya çalışmıştır. Çocukların 5 yaşından itibaren duygularını daha düzgün ve yakın ifadeler kullanarak ifade etmeye başlaması (Aksoy ve Çiftçi, 2009) göz önünde bulundurularak, bu somut ifadeler aslında çocukların o andaki mutluluklarını ve heyecanlarını belirtmede kullandıkları kelimeler olarak düşünülebilir.

Tablo 5 incelendiğinde Kategori 2 de çocukların tablet kullanıma yönelik olumlu düşüncelerine ilişkin kodlamalar yer almaktadır. Bu kodlamalara göre;

Kod1. Kendi resimlerine yönelik düşünceler: Araştırmaya katılan çocukların tablette neleri sevdikleri konusu sorulduğunda bütün özelliklerini ( $\mathrm{f}=4$; Ç3, Ç6, Ç12, Ç30) seven çocuklar dışındaki diğer çocuklar kendi çizdiği resmi (f=13; Ç8, Ç9, Ç11, Ç13, Ç14, Ç16, Ç27, Ç29, Ç35, Ç37, Ç39, Ç40, Ç43), resim çizmeyi ( $\mathrm{f}=5$; Ç2, Ç19, Ç28, Ç36, Ç38) sevdiklerini belirtmişlerdir. Kod2. Tablete ve uygulamaya yönelik düşünceler: Çocuklar renkleri ( $\mathrm{f}=6$; Ç1, Ç10, Ç18, Ç20, Ç26, Ç42), sesini ( $\mathrm{f}=2 ; \mathrm{C} 4$, Ç22), parlaklığını ( $\mathrm{f}=1$; Ç5), kalemleri (f=8; Ç7, Ç15, Ç17, Ç21, Ç25, Ç33, Ç34, Ç44), silmek ve geri almak tuşlarını (f=5; Ç23, Ç24, Ç31, Ç32, Ç41) sevdiklerini belirtmişlerdir. Bu konuya örnek olarak, Ç4: "Ses çıkarmasını sevdim," Ç25: "Tablette en çok kalemleri sevdim," diyerek tablet özelliklerini sevdiklerini belirtmiştir.

Tablo 5 incelendiğinde Kategori 3 de çocukların tablet kullanıma yönelik olumsuz düşüncelerine ilişkin kodlamalar yer almaktadır. Bu kodlamalara göre;

Kod1. Kendi resimlerine yönelik düşünceler: Çocuklara nelere sevmedikleri sorulduğunda sevmediği bir durum olmadığını belirten çocuk sayısı çoğunluktayken (f=17; Ç1, Ç3, Ç5, Ç7, Ç8, Ç9, Ç11, Ç12, Ç17, 
Ç25, Ç29, Ç30, Ç32, Ç34, Ç35, Ç36, Ç37), kendi çizdiği resmi beğenmeyen (f=7; Ç2, Ç6, Ç13, Ç14, Ç27, Ç28, Ç43) çocuklar bulunmaktadır. Kod2. Tablete ve uygulamaya yönelik düşünceler: Tablette bulunan silme özelliğini sevmeyen ( $\mathrm{f}=5$; Ç4, Ç23, Ç24, Ç39, Ç40), kalemlerden bazılarını sevmeyen ( $\mathrm{f}=7$; Ç10, Ç15, Ç16, Ç20, Ç38, Ç41, Ç42), sesini sevmeyen ( $\mathrm{f}=2$; Ç18, Ç21), uygulamada bulunan kenar boşluklarını beğenmeyen ( $\mathrm{f}=2$; Ç19, Ç22), uygulamadaki tuşları sevmeyen ( $\mathrm{f}=4$; Ç26, Ç31, Ç33, Ç44) çocuklar da çıkmıştır. Ç30: "Bütün yaptıklarımız hoşuma gitti" diyerek tabletle resim çizmek hakkında sevmediği bir nokta olmadığını ifade etmiştir. Ç39: "Silgiyi sevmedim” ve Ç23: "Bütün ekranı silen tuşu sevmedim" ifadeleri ile tabletteki silme özelliğini sevmediklerini belirtmişlerdir.

Tablo 5 incelendiğinde Kategori 4 de çocukların tablette resim çizmek dışındaki tercihlerine ilişkin kodlamalar yer almaktadır. Bu kodlamalara göre;

Kod1 Farklı nesneler: Tablette kendi portrelerini çizmek dışında neler çizmek istedikleri sorulduğunda cevap vermeyen çocuklar dışında (f=11; Ç3, Ç9, Ç13, Ç16, Ç20, Ç30, Ç31, Ç32, Ç33, Ç34, Ç41), tablette oyun oynamak isteyen ( $\mathrm{f}=1$; Ç1), çok şey çizmek istediğini ifade eden ( $\mathrm{f}=7$; Ç4, Ç11, Ç12, Ç22, Ç23, Ç24, Ç25), insan çizmek isteyen ( $\mathrm{f}=1$; Ç8) çocuklar bulunmaktadır. Diğer nesneler; kalp ( $\mathrm{f}=4$; Ç26, Ç35, Ç36, Ç40), araba ( $\mathrm{f}=3$; Ç2, Ç28, Ç39), bulut ( $\mathrm{f}=2 ;$ Ç14, Ç42), gülen yüz ( $\mathrm{f}=2 ; \mathrm{Ç19}$, Ç21), burun $(\mathrm{f}=1$; Ç15), uçak $(\mathrm{f}=1 ;$ Ç27) ve çiçektir ( $\mathrm{f}=1$; Ç38). Çocuklardan bir tanesi $(\mathrm{f}=1$; Ç29) tablette "özgürce resim çizmek” istediğini belirtmiştir. Kod2. Aile bireyleri: Anne ve babasını çizmek isteyen ( $\mathrm{f}=5$; Ç6, Ç7, Ç37, Ç43, Ç44) çocukların sayısı çoğunluktadır. Kod3. Hayvanlar: Diğer çocukların tercihleri hayvanlardır (f=4; Ç5, Ç10, Ç17, Ç18).

Tablo 5 incelendiğinde Kategori 5 de çocukların tablette resim çizmek hakkındaki görüşlerine ilişkin kodlamalar yer almaktadır. Bu kodlamalara göre;

Kod1. Olumlu düşünceler: Araştırmaya katılan çocukların çoğunluğunun ( $\mathrm{f}=32$; Ç1, Ç2, Ç3, Ç5, Ç6, Ç7, Ç9, Ç10, Ç11, Ç12, Ç13, Ç14, Ç15, Ç16, Ç19, Ç20, Ç23, Ç24, Ç25, Ç28, Ç29, Ç30, Ç31, Ç32, Ç33, Ç34, Ç35, Ç36, Ç37, Ç41, Ç42, Ç43) tabletle resim çizmeyi kalem kağıtla resim çizmeye tercih ettikleri, diğer çocukların (f=10; Ç4, Ç8, Ç17, Ç21, Ç22, Ç26, Ç27, Ç39, Ç40, Ç44) kalem kağıtla çizmeyi tablette resim çizmeye tercih ettikleri belirlenmiştir. Resim çizerken her ikisini tercih eden çocuk sayısı iki ( $\mathrm{f}=2$; Ç18, Ç38) olarak ortaya çıkmıştır. Çocuklara neden tableti seçtikleri sorulduğunda cevaplardan bazıları şu şekildedir. Ç5: "Tablette istediğimi yapabiliyorum. Kağıtta da yapabiliyorum ama silmeye uğraşıyorum", Ç8: "Tablette daha çok renk var. Kağıtta resim çizerken çok az renk var ve buradaki (tabletteki) şeyler daha güzel”, Ç9: "Çünkü tablette bir sürü boya var", Ç10: "Çünkü tablette kalemlerin ucu hiç bitmiyor", Ç14: "Çünkü tablette daha güzel resim yapıyorum”, Ç15: "Burada (tablette) her yeri boyayan boya da var. O kağıtta çok zaman alır”, Ç20: “İlk defa öğrendiğim için tablette resim çizmek çok eğlenceli”, Ç33: “Tablette silgi var silebiliyorsun. Keçeli kalemle yaptığında silemiyorsun” gibi cevaplar vermişlerdir. Kod2. Olumsuz düşünceler: Kağıdı tercih eden çocukların ise neden sorusuna cevapları şu şekildedir; Ç21: "Bunu [kâğıttaki resmi göstererek] ellerimizle boyayabiliyoruz bununla [tableti göstererek] boyayamıyoruz", Ç22: "Tableti çok izlerken gözlerimiz bozulur”, Ç40: “Çünkü bunu [kağıttaki resmi göstererek] daha güzel yaptım.”

Tablo 6. Öğretmenlerin ve Araştırmacıların Çocukların Tablette Çizdikleri Resimlere Yaklaşımlarına İlişkin Kategori ve Kodlamalar

\begin{tabular}{lccc}
\hline $\begin{array}{c}\text { Kategori 1: Öğretmenlerin } \\
\text { çocukların resimlerine } \\
\text { yorumlarına ilişkin } \\
\text { kodlamalar }\end{array}$ & $\begin{array}{c}\text { Kategori 2: Öğretmenlerin } \\
\text { çocukların tablet kullanımına } \\
\text { yorumlarına ilişkin kodlamalar }\end{array}$ & $\begin{array}{c}\text { Kategori 3: Araştırmacıların } \\
\text { çocukların resimlerine } \\
\text { yorumlarına ilişkin kodlamalar }\end{array}$ \\
\hline Kod 1 & Olumlu yorumlar & Olumlu Yorumlar & Olumlu duygu düşünce \\
\hline
\end{tabular}




\section{Öğretmenlerin ve Araştırmacıların Çocukların Tablette Çizdikleri Resimlere ve Çocukların Tablet Kullanımlarına Yönelik Yaklaşımları}

Araştırmaya katılan öğretmenlerin ve araştırmacıların çocukların tablette çizdikleri resimlere ve tablet kullanımlarına yönelik yaklaşımları; öğretmenlerin çocukların resimlerine yorumları, öğretmenlerin çocukların tablet kullanımına yorumları, araştırmacıların çocukların resimlerine yorumları kategorilerinde Tablo 6'de incelenmiş ve kodlamalara yer verilmiştir.

Tablo 6 incelendiğinde Kategori 1 de öğretmenlerin çocukların resimlerine yorumlarına ilişkin kodlamalar yer almaktadır. Bu kodlamalara göre;

Çalışmaya katılan öğretmenlere çocukların çizdikleri her iki resmi de karşılaştırmaları ve resimler hakkında yorum yapmaları istenmiştir. Kod1. Olumlu yorumlar: Ö2 çocukların tablet kullanırken daha yaratıcı olduklarını ve tabletteki boya seçeneklerinin çocukların ilgisini çektiğini, bu yüzden de çocukların bütün resmi tamamladıklarını dile getirmiştir. Ö2: "Normalde 3-6 yaş grubu çocuklardan bir sayfayı boya ile doldurması beklenmez ama tablette çocuk bunu daha kolay yapıyor. Resmi tamamliyor." Ö3'e göre de çocuklar tablet kullanırken resimlerine daha fazla eklemeler yaptığını ve rakamları da eklemesi ile resimlerini geliştirdiklerini ifade etmiştir. Ö3: "Tablette daha çok eklemeler yapmış ama kağıtta sınırlı kalmış. Mesela bir çocuk 2-3-4 gibi rakamları da ekleyerek resmini geliştirmiş.” Kod2. Olumsuz yorumlar: Ö1 çocukların tablette daha karmaşık resimler çizdiğini ve bazı çocukların tablete uyum sağlamakta zorlandıklarını dile getirmiştir. Ö1: "Aslında aynı şeyi yapmaya çalışmış ama tablette daha çok karmaşık olmuş."

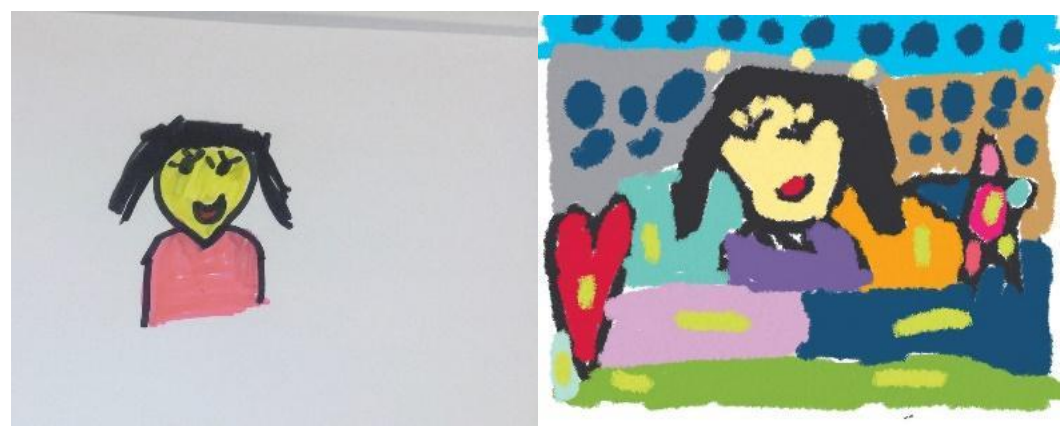

Ç23, Erkek, 6 yaş

(Kalem kağıtla ile çizilen) (Tablet ve kalemi ile çizilen)

Figür 2. Ekranın tamamını boyama çalışmasına bir örnek

Tablo 6 incelendiğinde Kategori 2 de öğretmenlerin çocukların tablet kullanımına yorumlarına ilişkin kodlamalar yer almaktadır. Bu kodlamalara göre;

Kod1. Olumlu yorumlar: Öğretmenlere çocukların tablet kullanımı hakkında görüşleri sorulduğunda Ö2: "Nası1 kullandıklarına göre doğru ya da yanlış buluyorum. Çocuğu geliştirecek bir şey izletmiyorlarsa, bence hiç kullanılmamalı. Geliştirici etkinlikler var, eğer o şekilde kullanılırsa bir saatten fazla bile kullanabilirler. Ö3'ün görüşleri Ö2 ile paralellik göstermektedir ve doğru kullanılmas1 yönünde görüş belirtmiştir. Ö3: "Yani hiç kullanılmaması değil, doğru kullanıldığı takdirde kullanılması taraftarıyım." Kod2. Olumsuz yorumlar: Ö1 tablet kullanımını çok doğru bulmadığını ve kullanım süresinin az olması gerektiğini şu sözleri ile dile getirmiştir. Ö1: "Çok doğru bulmuyorum yarım saatten fazla kullanmamaları gerekir." Ö2 ise velilerin tablet kullanımını gözetim altına almaları ve çocuklarının kendilerini geliştirici yönde kullanmalarına izin vermeleri gerektiğini savunmuştur. 

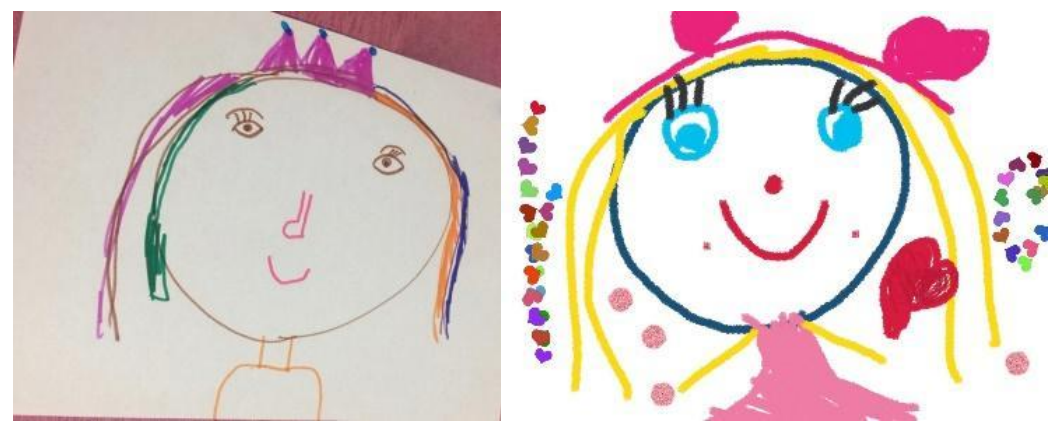

Ç17, Kız, 5 yaş

(Kalem kağıtla ile çizilen) (Tablet ve kalemi ile çizilen)

Figür 4. Farklı nesne (kalp) kullanımına bir örnek

\section{Tartışma, Sonuç ve Öneriler}

Erken çocukluk döneminde teknoloji kullanımının etkisi konusunda bilinenler henüz çok azken, teknolojinin çocuklar üzerindeki etkisi konusunda çok fazla araştırmaya ihtiyaç olduğu ortaya çıkmaktadır (Vandewater, 2007). Hala teknolojinin eğitimde kullanılması konusunda tartışmalar devam ederken, bu çalışma tablet bilgisayarların eğitimde kullanılabilirliği konusunda bir basamak oluşturabilir. Fakat, unutmamak gerekir ki, teknolojinin eğitimde verimli olabilmesi için etkili ve doğru şekilde kullanılması gerekmektedir ve bunun için ortam hazırlanmalıdır.

Okul öncesi dönem çocuklarının teknolojiyi etkili bir şekilde kullanmaları için velilere ve öğretmenlere büyük görevler düşmektedir. Okullarda teknoloji konusunda etkili bir eğitim verilebilmesi ve ev ortamında çocuklarının teknolojiden olumlu yönde faydalanabilmeleri için öğretmenlerin ve velilerin teknoloji konusunda bilinçli olmaları gerekmektedir. Araştırma sonucuna göre velilerin çoğunluğunun evlerinde teknolojiyi eğitici yönde kullandıklarını düşündükleri ortaya çıkmıştır. Fakat her kullanılan teknolojinin ve eğitici olarak lanse edilen çizgi filmlerin ve oyunların aslında eğitici ve öğretici olmadığg göz önünde bulundurulduğunda, velilerin bu konuda bilinçlenmesi gerekmektedir. Veliler evlerinde daha dikkatli bir yol izleyerek, çocukların teknoloji kullanımının onlar için faydalı ve sağlıklı olmasını sağlayabilirler (Neumann, 2015).

Öğretmenlerin teknoloji kullanımında zaman sınırlamasının önemli olduğunu düşündükleri için sadece belirli bir süre teknoloji kullanıma olumlu baktıkları ortaya çıkmıştır. Teknolojinin son yıllardaki gelişimi ve hayatımızdaki yeri düşünüldüğünde, öğretmenlerin teknolojiyi okul öncesi dönem eğitiminde etkili bir şekilde kullanabilmesi için öncelikle yeni teknolojik aletleri keşfetmesi ve kendi kullanması gerekmektedir (Franklin, 2007).

Çalışmanın sonucunda, 3-6 yaş grubu çocukların tablet ve tablet kalemini kullanmayı çok çabuk bir şekilde öğrendikleri ve bu teknolojik araçlarla kendilerini ifade edecek şekilde çizim yapabildikleri bulunmuştur. Araştırmacılar tarafından çocuklara verilen tablet kullanımı eğitimi ve uygulamanın tanıtımı kısa bir sürede yapılmış olmasına rağmen çocukların verilen komutları çok çabuk kavrayarak, tableti ve uygulamayı rahatlıkla kullandıkları görülmüştür. Bütün çocukların uygulamadaki renkleri, kalemleri, emojileri vb. özellikleri rahatlıkla kullandığg gözlemlenmiştir.

Araştırmaya katılan çocukların genelinin teknolojiye yönelik ilgileri olduğu görülmüştür. Araştırmada kullanılan tablet ve resim çiziminde kullanılan uygulama çocuklar tarafindan ilgi ile karşılanmıştır. Çocukların büyük bir çoğunluğunun tablette çizdikleri resimlere yönelik olumlu duygular besledikleri görülmüştür. Tablet uygulamasında yer alan geri alma ve silme tuşlarının çocuklar tarafından 
sıklıkla kullanıldığı incelenen video kayıtlarında ortaya çıkmıştır. Öğretmenler de bu yönde olumlu görüş belirterek, bu özellik sayesinde çocukların beğenmedikleri resimleri kağıtta yaptıklarında silmenin zor olduğunu ve kağıdı atmak zorunda kaldıklarını bu yüzden de tabletteki bu uygulamanın kağıt israfindan kurtaracağını dile getirmişlerdir.

Araştırmada çocuklara yöneltilen sorular doğrultusunda çocukların resim çizerken kısıtlanmak istemedikleri, daha çok özgürce resim çizmek istedikleri ortaya çıkmıştır. Araştırma esnasında çocukların tablet kullanıma yönelik çok ilgili oldukları ve kullanılan tabletin markasını dahi bildikleri görülmüştür. Çocukların büyük çoğunluğunun tablette resim çizmeyi geleneksel bir yöntem olan kalem kağıt ile resim çizmeye tercih ettikleri belirlenmiştir. Kalem kağıt uygulamasını tercih eden çocuklara neden tercih ettikleri sorulduğunda 3 yaş grubundaki çocukların ellerinin boya kalemleri ile boyanmasından ve ellerinin kirlenmesinden hoşlandıklarını dile getirdikleri görülmüştür. 36-48 aylık çocukların tablette çizdikleri resimlere karşı duyguları sorulduğunda daha büyük yaş grubunun soyut duygular ile ifade ettikleri duygularını daha somut duygular ile ifade ettikleri belirlenmiştir. Bunun dışında tablet uygulamasında yer alan farklı tondaki ve çeşitteki kalemler çocuklarının ilgisini çekmiştir. Çocukların ifadelerindeki bu bulguların Couse ve Chen (2010)'in yaptığı çalışmadakine benzerlik gösterdiği görülmüştür. Couse ve Chen (2010)'in bulgularına paralel olarak, bu çalışmada da çocukların tablet bilgisayar ve kalemini kullanmadaki heyecanı, ilgisi, odaklanmaları ve ifadelerindeki olumlu kelimeler göz önünde bulundurulduğunda böyle bir teknolojik aletin erken çocukluk döneminde öğrenme ve öğretme aracı olarak kullanılabileceği düşünülmektedir. Çocukların Ayrıca, araştırmacıların ve öğretmenlerin gözlemlerinde de tablette yapılan resimlerin daha yaratıcı, detaylı ve renkli olduğu ve tabletteki çizim alanını daha verimli kullandıkları ortaya çıkmıştır. Sonuç olarak, tablet kullanımının okul öncesi dönem çocuklarında resim çizme becerilerini arttıracağı düşünülmektedir. Benzer şekilde, Price, Jewitt ve Crescenzi’nin 2015 yılında yaptıkları çalışma sonucunda okul öncesi dönemde tablet kullanımının çocukların yazı yazma ve resim çizme becerilerini geliştirdiklerini göstermişlerdir.

Öğretmenlere uygulama sonucunda yöneltilen sorular doğrultusunda çocukların tablette çizdikleri resimlerde bütün sayfayı kullandıklarını ve çocukların daha yaratıcı resimler çizdiklerini düşündükleri görülmüştür. Araştırmaya katılan öğretmenlerin görüşlerine göre çocuklar tablet uygulamasında daha detaylı resimler çizmiş ve farklı nesneleri (örn: kalp, rakam) resimlerine dahil etmişlerdir. Yine, Couse ve Chen (2010)'in öğretmenler ve okul öncesi dönem çocukları ile yaptıkları bir çalışmada öğretmenlere göre çocuklar tablet bilgisayarlar ile çok daha keyifli resim çizmekte ve çizdikleri resimler beklentilerinin daha üzerinde olmaktadır.

Günümüzde artık kaçınılmaz olan teknoloji kullanımı, erken çocukluk eğitiminde de yer almaktadır. Böyle bir dijital toplumda da yapılacak şey, teknolojinin eğitimde nasıl etkili ve doğru kullanılacağı üzerinde durmaktır. Bu anlamda, araştırmanın sonuçlarına göre aşağıdaki öneriler geliştirilebilir;

Velilerin ev ortamında çocuklarının teknolojiyi daha verimli kullanmalarını sağlamak için bilinçlendirici etkinlikler düzenlenebilir.

Lisans eğitimi sırasında öğretmen adayları, etkili teknoloji ve internet kullanımı hakkında bilinçlendirilebilir. Öğretmen adaylarının sadece teknoloji ve internet kullanımı ile ilgili ders almalarının dışında gittikleri staj okullarında da bu bilgileri uygulamaları için firsat tanınabilir.

Çocukların teknolojiyi etkili ve verimli bir şekilde kullanmaları için öğretmenlerin sınıf içerisinde teknoloji kullanımını artırması ve çocukları bu konuda yönlendirmeleri sağlanabilir.

Milli Eğitim Bakanlığı Okul Öncesi Eğitim Programında yer alan kazanım ve göstergelere teknoloji ve internet ile ilgili kazanım ve göstergeler de eklenebilir.

Çalışmanın başka illerde de uygulanarak genellenebilirliği test edilmelidir. Bu çalışmanın sadece bir okuldaki çocuklar ile yapılmış olması bu çalışmanın sınırlılıklarındandır. Bu çalışmaya benzer şekilde tablet bilgisayarların okul öncesi eğitimde kullanılması ile ilgili çalışmalar daha çok katılımcı ile yapılabilir. 


\section{Extended Summary}

\section{Introduction}

The technology that has entered our lives in the last two decades has been closely affecting our life and culture. The dissemination of technology has also enabled the use of technology in the education process. Education policies have also been influenced by technology and new education projects have begun to be developed. Although some studies have been written against the use of technology in early-childhood, many studies have mentioned the positive effects of using technology in early-childhood education. Even though there is no study of the potential for the use of tablet computers and the stylus-interfaced technology in early-childhood education in our country, some studies conducted abroad provide information about how this technology can be used in the early childhood education. This present study is important to explore the viability of tablet computers in early childhood education for activities that support children's developmental process, considering that tablet computers will offer a unique learning experience for children.

The development of children in the preschool period is evaluated with the work they do. These assessments can often be considered as children's freelance drawing and writing work. This study was designed to understand how the tablet computers can be used in this sense in education. In line with this purpose, the children were asked to draw their self-portraits using both traditional tools, paper-and-pencil, and the stylus-interfaced technology. The research questions of this study are:

- What do parents think about their children's use of technology?

- What are preschool children's thoughts about drawing on tablet computers?

- What are preschool teachers and researchers' opinions about the drawings that children have made with tablet computers?

- What are preschool teachers' opinions on their students' use of technology?

This exploratory research was conducted to investigate the experiences of preschool children on tablet computer use and to learn more about how this technological tool can be used as a learning tool. The unit of analysis in the study was the child and the interaction of these children with both traditional tools (pencils, markers, crayons) and the stylus-interfaced technology was investigated. This study included 44 (25 girls, 19 boys) three to six-year-old children who attend a private school in Konya, their parents, and teachers participated in the study. A parent background survey was distributed, which was about demographics, the types of technology available in the home, and the patterns of children's technology use at home.

In the first phase of the study, each class teacher asked children to draw their own portraits on paper. In the second phase of the study, a quiet environment outside the classroom was created for each child to meet and warm-up with the researchers. Researchers provided instructions on how to use the tablet and the drawing application. Then, the children were asked to draw their self-portraits with the tablet application. Finally, interviews were held to learn about the children's opinions with the application and the tablet in general. In addition to the data received from the children, focus group interviews were conducted with the teachers for 55 minutes. The teachers were asked to compare the paper and tablet drawings of each child. Content analysis method was used to analyze the data. Video recordings were used to support observational data for the consistency of what the children said during the interviews and what they did during the drawing sessions. The results of the children's data were also supported by teachers' interviews. 


\section{Findings}

The findings were organized under 3 themes. These themes are: parents' approaches to technology, children's opinions about technology and tablet use, and teachers and researchers' approaches about technology use in education and the drawings.

Parents' approaches to technology theme was categorized and analyzed under: demographics and parents' thoughts about using technology, the types of technology and applications available in the home, and the patterns of children's technology use at home. Children's opinions about technology and tablet use theme was categorized and analyzed under: children's feelings about the use of tablets, children's positive thoughts on tablet use, children's negative thoughts on tablet use, children's preferences other than drawing pictures on the tablet, children thoughts about drawing pictures on the tablet. Teachers and researchers' approaches about technology use in education and the drawings theme was categorized and analyzed under: the teachers' comments on the drawings, their opinions on children's tablet use, and the researchers' comments on the drawings.

\section{Discussion and Conclusion}

As a result of the study, it is found that children in the 3 to 6-years age group were able to quickly learn to use the stylus-interfaced technology and they were able to draw to represent themselves with this technological tool. Although the introduction sessions of the stylus-interfaced technology and the application was made in a short period of time, the children were able to quickly grasp the commands and they became comfortable using the tablet and the application.

It is found that all children in the study used the colors, brushes, emoji in the application and the majority of children prefer to draw pictures on a tablet when compared to a traditional method. In addition, the observations of researchers and teachers have revealed that the drawings made on the tablet are more creative, detailed and colorful, and that the children use the drawing space more efficiently in the tablet computers. The children were interested and persisted in learning with this new technology.

The stylus-interfaced technology appears to be a viable tool in early childhood education for activities that support children's developmental process. It is suggested that trainings on effective and efficient use of technology can be provided for parents and teachers and the use of technology in a careful and efficient manner should be increased in the classroom in order for the children to adapt to the developing technology. 


\section{Kaynakça / References}

Akkoyunlu, B. \& Tuğrul, B. (2002). Okulöncesi çocukların ev yaşantısındaki teknolojik etkileşimlerinin bilgisayar okuryazarlığı becerileri üzerindeki etkisi. Hacettepe Üniversitesi Eğitim Fakültesi Dergisi, 23(23),12-21. Retrieved from http://dergipark.ulakbim.gov.tr/hunefd/article/view/5000048843/5000046164

Aksoy, A. \& Çiftçi, H. D. (2009). Duygusal gelişim. Aral, N. Duman, T.(Ed.). Eğitim psikolojisi içinde (ss. 178-208). İstanbul: Kriter Yayınları.

Bencik-Kangal, S. \& Özkızıklı, S. (2015). Teknoloji ve eğitim. Bayhan, B. (Ed.). Okul öncesi eğitimde teknolojinin rolü içinde (ss. 9-31). Ankara: Hedef CS Basın Yayın.

Bogdan, R., \& Biklen, S. (2007). Qualitative research for education: An introduction to theory and practice (5th ed.). Upper Saddle River, NJ: Prentice Hall.

Buckingham, D. (2007). Beyond technology: Children's learning in the age of digital culture. Cambridge: Polity Press.

Blackwell, C. K., Lauricella, A. R., \& Wartella, E. (2014). Factors influencing digital technology use in early childhood education. Computers \& Education, $77, \quad 82-90$. https://doi.org/10.1016/j.compedu.2014.04.013

Clements, D. H. \& Sarama, J. (2014). Learning and teaching early math: The learning trajectories approach (2nd ed.). New York, NY: Routledge.

Couse, L.J. \& Chen, D. W. (2010). A tablet computer for young children? Exploring its viability early childhood education. Journal of Research on Technology in Education, 43(1), 75-98. https://doi.org/10.1080/15391523.2010.10782562

Çeliköz, N. \& Kol, S. (2013). Bilgisayar destekli öğretimin (BDÖ) altı yaş çocuklarına zaman ve mekân kavramlarını kazandırmaya etkisi. Kastamonu Üniversitesi Kastamonu Eğitim Dergisi, 24(4), 18031820. Retrieved from http://dergipark.gov.tr/kefdergi/issue/27734/327563

Creswell, J. W., \& Creswell, J. D. (2017). Research design: Qualitative, quantitative, and mixed methods approaches. Thousand Oaks, CA: Sage publications.

Demir, N. (2007). Okul öncesi ögrrencilerine renk kavramının kazandırılmasında bilgisayar destekli ve geleneksel ögretim yöntemlerinin karşılaştırılması (Yayımlanmamış doktora tezi). Selçuk Üniversitesi Sosyal Bilimler Enstitüsü, Konya.

Doğan, D., Çınar, M., \& Seferoğlu, S. S. (2016). "One laptop per child” projects and FATIH project: A comparative examination. SDU International Journal of Educational Studies, 3(1), 1-26. Retrieved from http://dergipark.ulakbim.gov.tr/sduijes/article/view/5000137824/5000165355/ 
Franklin, C. (2007). Factors That Influence Elementary Teachers Use of Computers. Journal of Technology and Teacher Education, 15(2), 267-293. Retrieved from https://www.learntechlib.org/primary/p/19833/.

Gall, M.D., Gall, J.P., \& Borg, W.R. (2007). Educational research: An introduction (8th ed.). Boston: Pearson.

International Society for Technology in Education. (2017). ISTE Standards. Retrieved from https://www.iste.org/standards/standards

Kesicioğlu, O. S. (2016). Okul öncesi dönemde bilgisayar ve matematik. Akman, B. (Ed.) Okul öncesi matematik ĕgitimi içinde (ss. 236-246). Ankara: Pegem Akademi.

Kitzinger, J. (1995). Qualitative research: introducing focus groups. British Medical Journal, 31(1), 299302. doi: https://doi.org/10.1136/bmj.311.7000.299

McCarick,K. \& Xiaoming,L. (2007). Burried treasure: The impact of computer use on young childrens' social, cognitive, language development and motivation. AACE Journal,15(1),73-95. Retrieved from https://eric.ed.gov/?id=EJ805602

McKenney, S., \& Voogt, J. (2009). Designing technology for emergent literacy: The PictoPal initiative. Computers \& Education, 52(4), 719-729. https://doi.org/10.1016/j.compedu.2008.11.013

Miller, V. (2011). Understanding digital culture. Sage Publications. London: SAGE.

Neumann, M. M. (2014). An examination of touch screen tablets and emergent literacy in Australian preschool children. Australian Journal of Education, 58(2), 109-122. https://doi.org/10.1177/0004944114523368

Neumann, M. M. (2015). Young children and screen time: Creating a mindful approach to digital technology. Australian Educational Computing, 30(2). Retrieved from: http://journal.acce.edu.au/index.php/AEC/article/view/67

Outhwaite, L. A., Gulliford, A., \& Pitchford, N. J. (2017). Closing the gap: Efficacy of a tablet intervention to support the development of early mathematical skills in UK primary school children. Computers \& Education, 108, 43-58. https://doi.org/10.1016/j.compedu.2017.01.011

Özdemir, S. \& Çetin, E. (2015). Teknolojik ürünler ve teknolojik ürünlerin sınıfta kullanımı. Bayhan, B. (Ed.). Okul öncesi eğitimde teknolojinin rolü içinde (ss. 9-31). Ankara: Hedef CS Basın Yayın.

Özer, S. (2009). Türk örnekleminde bir adam çiz testi: Cinsiyet ve sosyoekonomik düzeyin etkileri. Çocuk ve Gençlik Ruh Să̆lı̆̆ Dergisi, 16(2), 93-102. Retrieved from http://openaccess.dogus.edu.tr/handle/11376/163\#sthash.krQ3LZvq.dpbs 
Patton, M. Q. (2014). Nitel araştırma ve değerlendirme yöntemleri (Çev: M. Bütün \& S. B. Demir). Ankara: Pegem Akademi.

Plowman, L., Stevenson, O., McPake, J., Stephen, C., \& Adey, C. (2012). Parents, pre-schoolers and learning with technology at home: Some implications for policy. Journal of Computer Assisted Learning, 27, 361-371. https://doi.org/10.1111/j.1365-2729.2011.00432.x

Price, S., Jewitt, C., \& Crescenzi, L. (2015). The role of İpads in pre-school children's mark making development. Computer \& Education, $\quad 87(2015), \quad 131-141$. https://doi.org/10.1016/j.compedu.2015.04.003

Tekin, A. \& Polat, E. (2014). Eğitimde teknoloji politikaları: Türkiye ve bazı ülkeler. Eğitimde kuram ve uygulama, 10(5), 1254-1266.

Ter Laack, J., de Goede, M., \& Aleva, A. (2005). The Draw-A-Person Test: An indicator of children's cognitive and socio-emotional adaptation? Journal of Genetic Psychology, 166(1), 77-93. https://doi.org/10.3200/GNTP.166.1.77-93

Trepanier-Street, M. L., Hong, S. B., \& Bauer, J. C. (2001). Using technology in Reggio- inspired long-term projects. Early Childhood Education Journal, 28(3), 181-188. https://doi.org/10.1023/A:1026547302846

Vandewater, E. A., Rideout, V. J., Wartella, E. A., Huang, X., Lee, J. H., \& Shim, M. S. (2007). Digital childhood: Electronic media and technology use among infants, toddlers, and preschoolers. Pediatrics, 119, 1006-1015. http://dx.doi.org/10.1080/17482798.2016.1254095

Vernadakis, N., Avgerinos, A., Tsitskari, E., \& Zachopoulou, E. (2005). The use of computer assisted instruction in preschool education: Making teaching meaningful. Early Childhood Education Journal, 33(2), 99-104. Retrieved from https://eric.ed.gov/?id=EJ747026

Wittenburg, P., Brugman, H., Russel, A., Klassmann, A., \& Sloetjes, H. (2006, May). Elan: A professional framework for multimodality research. Paper presented at the 5th International Conference on Language Resources and Evaluation, Genoa, Italy. Retrieved from http://www. lrecconf.org/proceedings/lrec2006/

Wong, S. S. H. (2015). Mobile digital devices and preschoolers' home multiliteracy practices. Language \& Literacy: A Canadian Educational E-Journal, 17(2). Retrieved from https:// journals.library.ualberta.ca/langandlit/index.php/langandlit/article/.../18367

Yıldırım, A. \& Şimşek, H. (2013). Sosyal bilimlerde nitel araştırma yöntemleri. (9. Baskı). Ankara: SeçkinYayıncılık. 


\section{EK-1}

\begin{tabular}{|c|c|c|c|c|c|c|c|c|}
\hline$\underset{\mathbf{U}}{\text { KOD }}$ & $\begin{array}{c}\text { CINSIYY } \\
\text { ET }\end{array}$ & $\begin{array}{c}\text { YASS } \\
\text { I }\end{array}$ & $\underset{\mathbf{U}}{\text { KOD }}$ & $\begin{array}{c}\text { CINSSIY } \\
\text { ET }\end{array}$ & $\begin{array}{c}\text { YASS } \\
\text { I }\end{array}$ & $\underset{\mathbf{U}}{\text { KOD }}$ & $\begin{array}{c}\text { CINSIYY } \\
\text { ET }\end{array}$ & YAŞ \\
\hline Ç1 & K & 3 & Ç16 & $\mathrm{K}$ & 5 & Ç31 & E & 5 \\
\hline Ç2 & K & 3 & Ç17 & $\mathrm{K}$ & 5 & Ç32 & E & 6 \\
\hline Ç3 & $\mathrm{K}$ & 3 & Ç18 & E & 5 & Ç33 & K & 6 \\
\hline Ç4 & E & 3 & Ç19 & K & 5 & Ç34 & K & 6 \\
\hline Ç5 & K & 4 & Ç20 & K & 6 & Ç35 & E & 6 \\
\hline Ç6 & $\mathrm{K}$ & 4 & Ç21 & $\mathrm{K}$ & 6 & Ç36 & E & 5 \\
\hline Ç7 & K & 4 & Ç22 & E & 5 & Ç37 & K & 6 \\
\hline Ç8 & $\mathrm{E}$ & 3 & Ç23 & E & 6 & Ç38 & K & 6 \\
\hline Ç9 & $\mathrm{E}$ & 3 & Ç24 & E & 5 & Ç39 & E & 6 \\
\hline Ç10 & $\mathrm{E}$ & 3 & Ç25 & $\mathrm{K}$ & 6 & Ç40 & K & 6 \\
\hline Ç11 & K & 5 & Ç26 & E & 5 & Ç41 & E & 6 \\
\hline Ç12 & $\mathrm{E}$ & 4 & Ç27 & $\mathrm{E}$ & 5 & Ç42 & E & 6 \\
\hline Ç13 & K & 5 & Ç28 & K & 6 & Ç43 & E & 6 \\
\hline Ç14 & K & 4 & Ç29 & $\mathrm{E}$ & 5 & Ç44 & K & 6 \\
\hline Ç15 & $\mathrm{E}$ & 5 & Ç30 & $\mathrm{E}$ & 6 & & & \\
\hline
\end{tabular}

